\title{
HYDRAULIC STABILITY AND OVERTOPPING PERFORMANCE OF A NEW TYPE OF REGULAR PLACED ARMOUR UNIT
}

\begin{abstract}
Bas Reedijk $^{1}$, Tamara Eggeling ${ }^{1}$, Pieter Bakker ${ }^{1}$, Robert Jacobs ${ }^{1}$, Markus Muttray ${ }^{1}$
The XblocPlus is a new type of interlocking single layer armour units that is placed with uniform orientation. This is novel and different from all other single layer, interlocking armouring systems. The hydraulic stability of the XblocPlus breakwater armour unit was tested in 2D and 3D hydraulic model tests. Wave overtopping tests were performed to determine the roughness coefficients of the EurOtop overtopping formula for the XblocPlus. Model tests on a rubble mound breakwater with XblocPlus armour included 2D tests with a 1:30 seabed slope and with 1:2 and 3:4 breakwater slopes and 3D model tests with a flat seabed and with a 3:4 breakwater slope. Wave heights up to $150 \%$ of the design wave height were tested in the $2 \mathrm{D}$ tests and up to $200 \%$ with wave directions $0^{\circ}$ to $60^{\circ}$ in the $3 \mathrm{D}$ tests. No armour unit displacements were observed in 2D tests with 1:2 slope. In the 2D tests with 3:4 slope one armour unit was displaced when the wave height reached $159 \%$ of the design wave height. No damage to the XblocPlus armour layer was observed in the $3 \mathrm{D}$ tests. A roughness coefficient of 0.45 was deduced from overtopping tests with wave heights of $60 \%$ to $100 \%$ of the design wave height. The model test results indicate little or no influence of wave steepness on XblocPlus stability and no adverse influence of wave obliquity while the seabed slope in front of the breakwater may have some impact on the XblocPlus armour layer stability.
\end{abstract}

Keywords: rubble mound breakwater, single layer armour unit, interlocking, regular placement, XblocPlus, hydraulic stability, overtopping, roughness coefficient

\section{INTRODUCTION}

Concrete armour units are widely used for the protection of breakwaters and seawalls. At present single layer, interlocking armour units are mostly applied. These armour units are placed on a staggered grid with almost randomly varying orientation. Armour units should be resting on three points, on the breakwater slope and on two armour units of the next lower row. Hence, the weight of an armour unit is at least partly used to stabilise two armour units in the next lower row. At the same time this unit is stabilised by part of the weight of two armour units in the next higher row. This interaction between neighbouring armour units is commonly called interlocking.

The random orientation of armour units results in a highly flexible matrix of interacting concrete blocks that can easily adjust to settlements or other deformation of the breakwater slope. Gaps in the armour layer, for example due to extraction of an armour unit, may even be closed by re-arrangement of surrounding armour units. This effect is called 'self-healing' capacity of interlocking armour layers (Muttray and Reedijk, 2009).
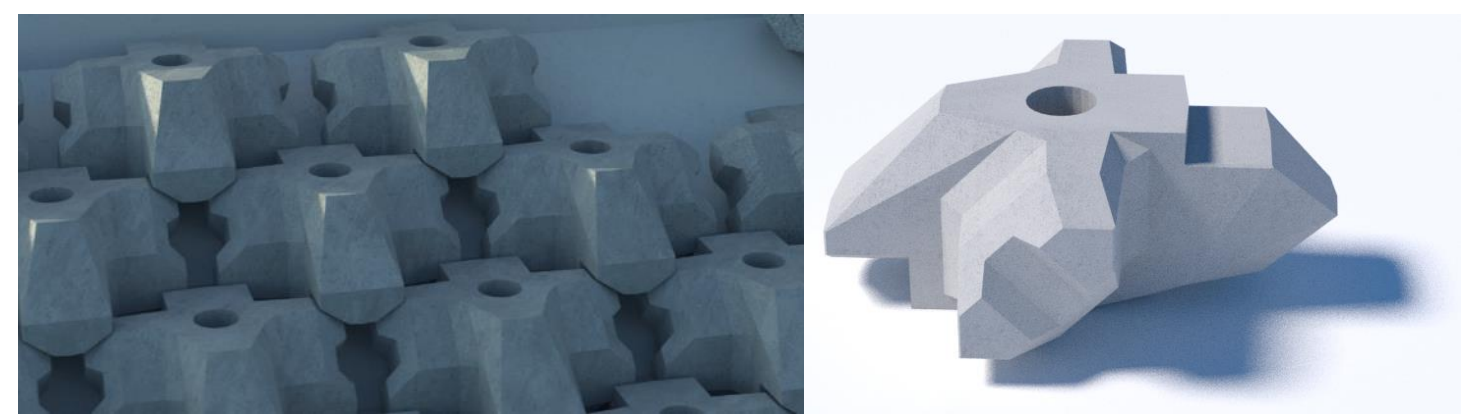

Figure 1: XblocPlus placement pattern (left) and side view of unit (right)

The placement of interlocking armour units on a breakwater slope has to meet strict requirements with respect to armour unit position and contact points with neighbouring units and slope. These requirements in combination with (i) the random variation of the unit orientation, (ii) limited visual control during placement and (iii) irregularities of the breakwater slope may complicate the placement and may have an adverse effect on placement rates. In order to facilitate the placement DMC started the development of an interlocking armour unit that is placed with uniform orientation. The new armour unit is called XblocPlus and is shown in Fig. 1. The hydraulic stability of the XblocPlus breakwater armour unit was tested in 2D and 3D hydraulic model tests. Wave overtopping tests were performed to determine the hydraulic performance of XblocPlus with regard to wave overtopping. Test results and conclusions regarding the hydraulic stability and hydraulic design of the new type of armour unit are presented in this paper.

\footnotetext{
${ }^{1}$ Delta Marine Consultants, H.J. Nederhorststraat 1, Gouda, 2801 SC, The Netherlands
} 


\section{ARMOUR UNIT DEVELOPMENT}

Today's single layer, interlocking armour units like Xbloc or Accropode ${ }^{\mathrm{TM}}$ are to be placed with randomly varying orientation to achieve a properly functioning armour layer. An inadequate variation of the armour unit orientation will result in a more regular appearance of the armour layer; the packing density and the concrete use will be increased and the reduced porosity of the armour layer may cause larger wave overtopping (Muttray et al., 2005). Nonetheless we see on breakwater construction sites a preference for more regular placement of interlocking armour units as it is requires less intuition and is mostly faster. This was the main trigger for the development of a single layer interlocking armour unit with a regular placement pattern.

Like other single layer, interlocking armour units XblocPlus is placed on a staggered grid, i.e. the position of each armour units on the breakwater slope is defined. The XblocPlus units are resting on the slope and on two units of the next lower row; they are stabilised by two units of the next higher row (see Fig. 1). In this sense the XblocPlus interlocking is very much the same as for other single layer armour units. However, the armour unit orientation of XblocPlus does not vary; all units are placed with the same orientation. Hence, the contact points between units are invariable. This is novel and different from all other single layer, interlocking armouring systems. A specific design of contact points is possible through this (Jacobs et al., 2018).

The idea behind the XblocPlus development was an armour unit that can be placed easier and faster. For that reason the armour unit are placed with a uniform orientation. Further to this the XblocPlus contact points are designed such that armour units are guided into the target position during placement (DMC, 2018). The shape development of the XblocPlus was performed in successive steps starting with the basic form. At a later stage the central opening was introduced that prevents water pressure build-up under the unit during wave run-up and run-down. Finally the contact points were optimised for interlocking. During these development stages the hydraulic stability of the new armour unit were tested. Test results that refer to various XblocPlus concept stages can be found amongst others in Vos (2017) addressing XlocPlus units without central opening and in Rada Mora (2017) referring to XblocPlus units with less refined contact points. Other model tests addressed the effect of underlayer grading on XblocPlus stability (van den Berg, 2018) and the stability of XblocPlus units at the transition to the crest berm (Janssen, 2018). The test results presented in this paper refer to the final XblocPlus armour unit shape.

\section{D MODEL TEST SET-UP}

2D model tests were performed in the DMC wave flume in Utrecht (NL). The flume is $25 \mathrm{~m}$ long and $0.6 \mathrm{~m}$ wide. It is equipped with a fully absorbing piston type spectral wave maker. Waves are measured by resistance type wave gauges; reflection analysis is based on the Mansard and Funke approach (1980).

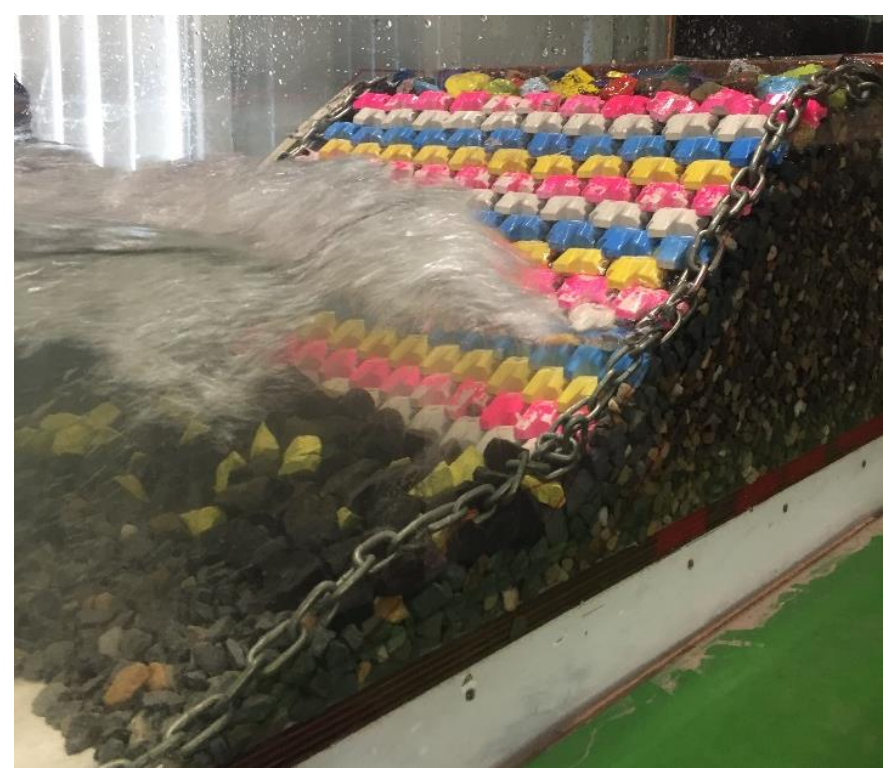

Figure 2: XblocPlus armoured 3:4 breakwater slope in the DMC wave flume 
The tests were performed with a 1:30 seabed slope in front of the structure. A rubble mound breakwater with XblocPlus armouring was tested. The weight of the XblocPlus was $59.4 \mathrm{~g}$ (density $\left.2.33 \mathrm{~g} / \mathrm{cm}^{3}\right)$. Stones of $3-6 \mathrm{~g}(5 \%$ to $10 \%$ of the armour unit weight) were applied for the underlayer; the core was made of stones with sieve diameter $8-11.6 \mathrm{~mm}$. Two breakwater cross sections were tested; a structure with a gentle 1:2 slope with $14.0 \mathrm{~cm}$ freeboard and a structure with a steeper 3:4 slope with $12.4 \mathrm{~cm}$ freeboard (Fig. 2). The water depth at the toe of the structure was $21.0 \mathrm{~cm}$. Additional tests with water depth $31.0 \mathrm{~cm}$ were performed with the 3:4 breakwater (Fig. 3).

Wave heights were measured by three wave gauges on the 1:30 seabed slope in front of the structure. Wave overtopping was measured at the crown wall. An overtopping chute was connected to the crown wall, overtopping was collected in a bucket and was weighed after the test. Rocking of armour units was assessed by visual observation during the tests. Settlements and displacement of armour units were analysed from photos taken before and after the tests.

The design wave height for the XblocPlus armour units tested is $9.8 \mathrm{~cm}$ (significant wave height, $\left.H_{s}\right)$. This is based on a stability number $\mathrm{N}_{\mathrm{s}}=\mathrm{H}_{\mathrm{s}} /\left(\Delta \mathrm{D}_{\mathrm{n}}\right)$ of 2.5 (with relative density, $\Delta$ and nominal rock diameter, $D_{n}$ ). The relative freeboard, $R_{c} / H_{s}$ of the breakwater was 1.27 (3:4 slope) and 1.43 (1:2 slope). Stability tests were performed as a sequence of tests with stepwise increasing wave height and constant wave steepness. The initial wave height was $60 \%$; wave heights were increased by increments of $10 \%$ or $20 \%$ up to about $150 \%$ (percentages refer to the design wave height, $\mathrm{H}_{\mathrm{s}}$ of $9.8 \mathrm{~cm}$ ). JONSWAP wave spectra were applied for the tests; the test duration was 1,000 waves. Test series were conducted with wave steepness, $\mathrm{s}_{0, \mathrm{p}}$ (the ratio of wave height, $\mathrm{H}_{\mathrm{s}}$ at the wave paddle and deep water peak wave length, $\left.\mathrm{L}_{0, \mathrm{p}}\right)$ of $0.01,0.02,0.04$ and 0.06 .

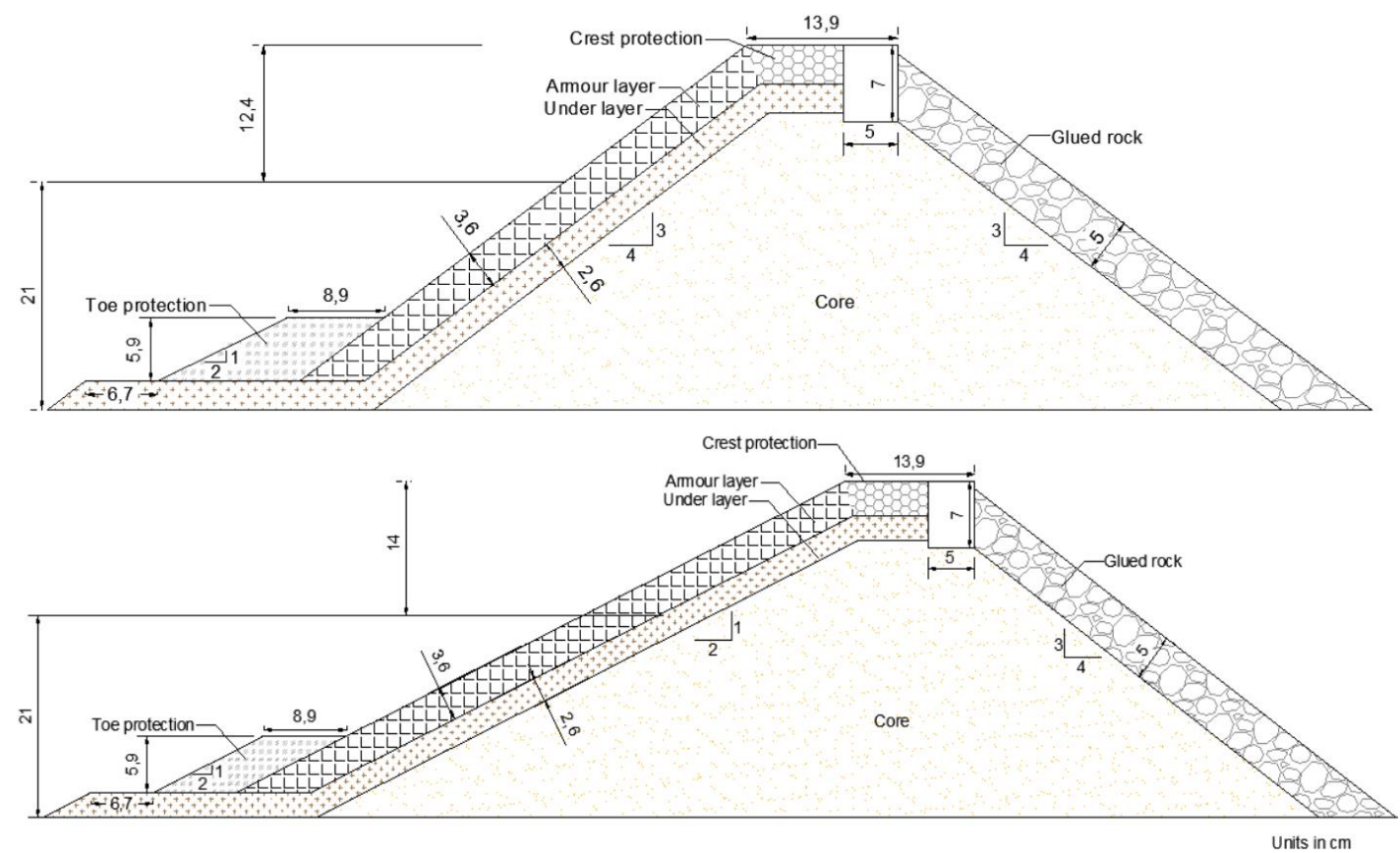

Figure 3: Cross sections of 2D breakwater model with 3:4 slope (top) and 1:2 slope (bottom)

\section{D MODEL TEST SET-UP}

3D model tests were performed in the wave basin of Ludwig Franzius Institute, University Hannover (Germany). The basin is $40 \mathrm{~m}$ by $25 \mathrm{~m}$ large and is equipped with 72 piston boards of $0.4 \mathrm{~m}$ width with active absorption system. The incident wave conditions were measured by a CERC 6-gauge-array with ultrasonic sensors. An additional ultrasonic wave gauge measured the waves at the toe of the structure.

The tests were performed with a flat seabed in front of the structure. A rubble mound breakwater with 3:4 slope and with XblocPlus armouring was tested (Fig. 4 and Fig. 5). The length of the test section was $1.80 \mathrm{~m}$. The weight of the XblocPlus was $58.4 \mathrm{~g}$ (density $2.33 \mathrm{~g} / \mathrm{cm}^{3}$ ). Stones with grading $12-$ $16 \mathrm{~mm}$ were applied for the underlayer; the core was made of stones with sieve diameter $8-16 \mathrm{~mm}$. The toe consisted of a layer of stones with grading $11.2-16 \mathrm{~mm}$ and was stabilised by concrete slabs of size 30 by $30 \mathrm{~cm}^{2}$ with $4 \mathrm{~cm}$ thickness. The breakwater had a total height of $90 \mathrm{~cm}$ and was tested with water 
depth $60 \mathrm{~cm}$ (30 cm freeboard). Additional overtopping tests were performed with water depth $75 \mathrm{~cm}$ (15 cm freeboard).

Wave overtopping was measured on the breakwater crest that was protected with XblocPlus armour units; the crest width was 3 armour units. An overtopping chute was resting on the crest armour (at distance $3 \mathrm{D}_{\mathrm{n}}$ from the seaward edge of the crest). Overtopping was collected in an overtopping unit and was weighed continuously during testing. Settlements and displacement of armour units were analysed from photos taken before and after the tests.
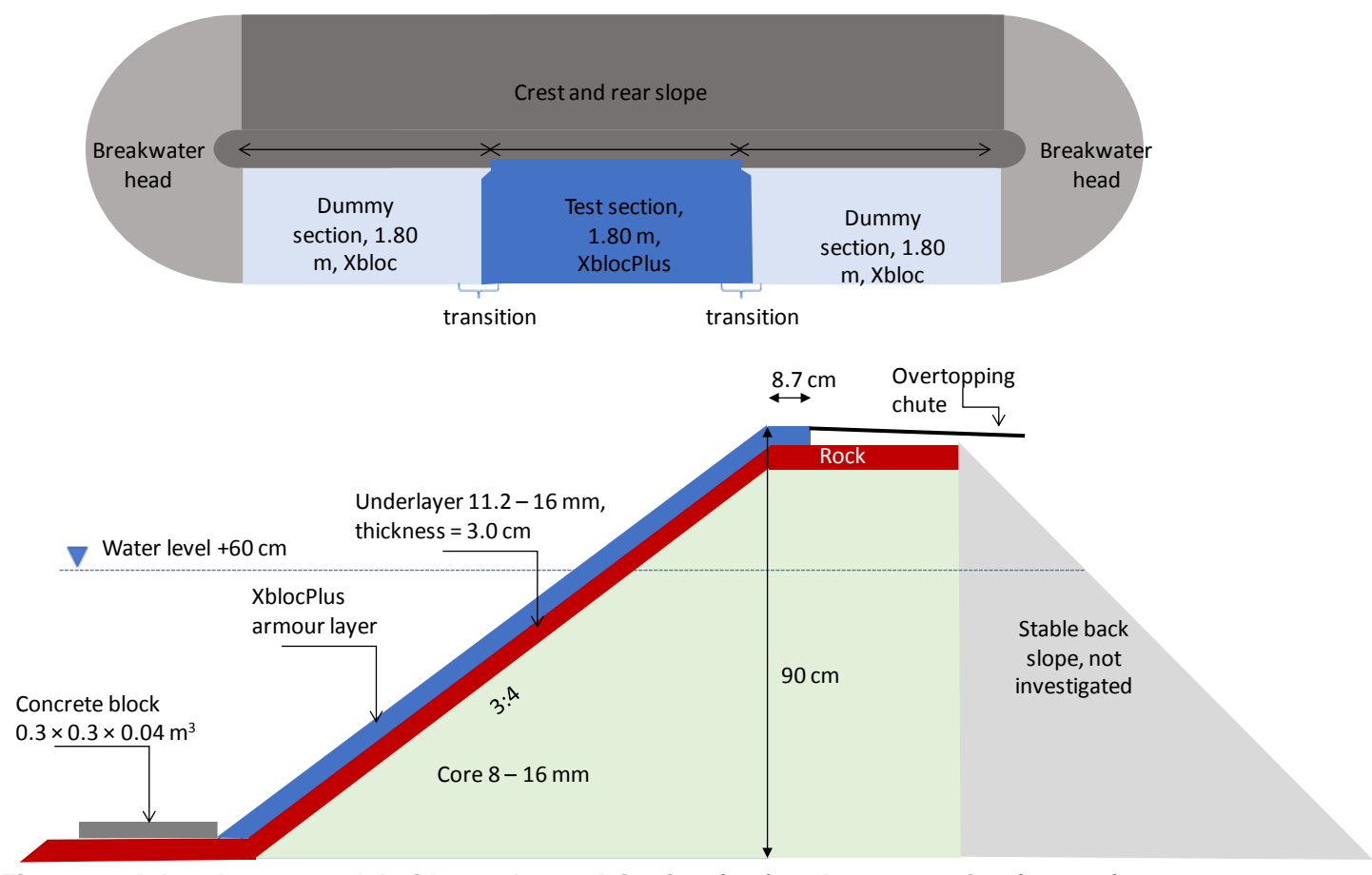

Figure 4: 3D breakwater model with 3:4 slope, plain view (top) and cross section (bottom)

The design wave height for the XblocPlus armour units tested, $\mathrm{H}_{\mathrm{s}}$ is $9.7 \mathrm{~cm}$ (based on a stability number $\mathrm{N}_{\mathrm{s}}=\mathrm{H}_{\mathrm{s}} /\left(\Delta \mathrm{D}_{\mathrm{n}}\right)$ of 2.5). The relative freeboard, $\mathrm{R}_{\mathrm{c}} / \mathrm{H}_{\mathrm{s}}$ of the breakwater was $3.09(60 \mathrm{~cm}$ water depth) and 1.55 (75 cm water depth). Stability tests were performed as a sequence of tests with stepwise increasing wave height and constant wave steepness. The initial wave height was $60 \%$; wave heights were increased by increments of $20 \%$ to about $160 \%$ (percentages refer to the design wave height, $\mathrm{H}_{\mathrm{s}}$ of $9.7 \mathrm{~cm}$ ). Stability tests and overtopping tests were conducted with wave directions $0^{\circ}$ (head-on waves), $30^{\circ}$ and $60^{\circ} \mathrm{JONSWAP}$ wave spectra were applied; the test duration was 1,000 waves. Test series were conducted with wave steepness, $\mathrm{s}_{0, \mathrm{p}}$ of 0.02 and 0.04 . Additional 6 tests were performed with wave heights varying from $160 \%$ to $200 \%$ of the design wave height, with wave direction $0^{\circ}$ and included longer waves (wave steepness $\mathrm{s}_{0, \mathrm{p}}$ of 0.06 ). A test with $258 \%$ conditions was interrupted after 5 minutes as the overtopping measuring devices got damaged (shown in brackets in Fig. 7).

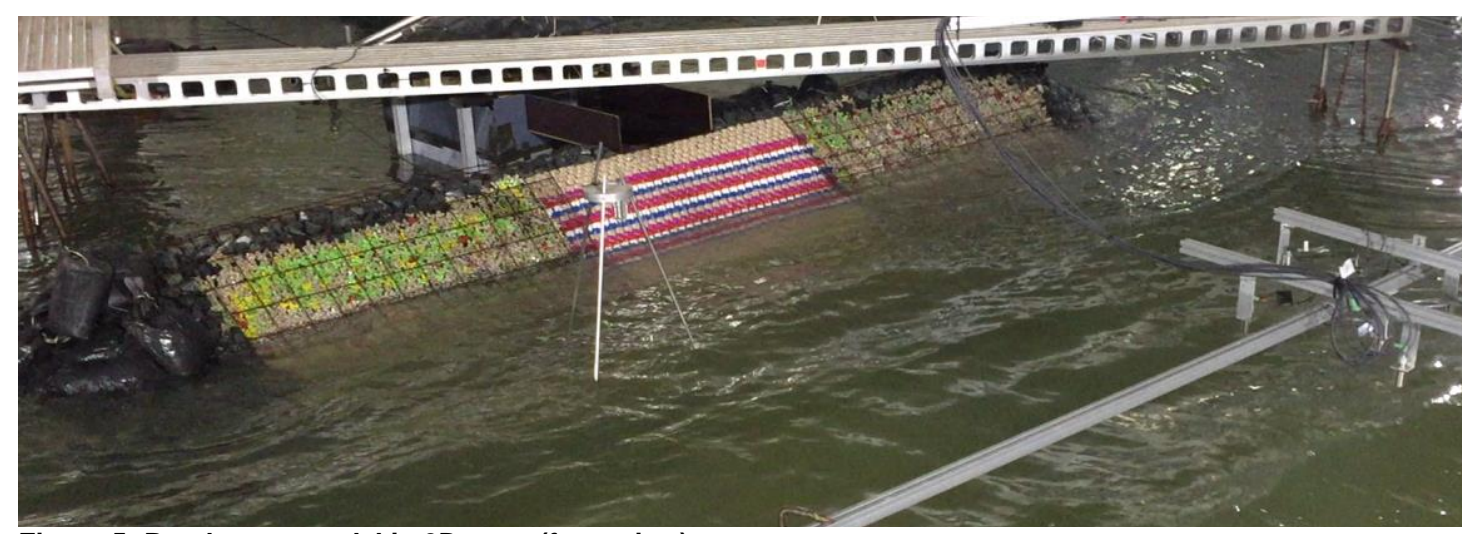

Figure 5: Breakwater model in 3D tests (front view) 


\section{RESULTS FROM 2D STABILITY TESTS}

Three types of armour layer damage were considered in the 2D tests. Rocking refers to repeated back and forth movements (typically more than $2 \%$ of the waves) of a specific armour unit and is determined by visual observations during the tests. Displacement refers to a significant shift or rotation of an armour unit (typically such that is no longer interlocking). Settlements refer to a general compaction of the armour layer (typically resulting in higher packing density on the lower slope and opening up of the armour layer on the upper slope near the crest). The hydraulic stability of armour units on the breakwater slope, i.e. from the toe up to but not including the transition to the crest was investigated. The stability of XblocPlus units at the transition from slope to crest berm and on the crest was not considered.

No armour unit displacements were observed in tests with 1:2 slope (Fig. 6, overload refers to $125 \%$ condition). Rocking of armour units was observed at the transition from slope to crest berm and on the crest berm but not on the breakwater slope. This is important to note since rocking may cause breakage of unreinforced concrete armour units. In tests with 3:4 slope armour unit displacement was observed in a single test. The water level was increased by $10 \mathrm{~cm}$ in this test series (water depth at the toe of the structure was $31 \mathrm{~cm}$ ). The wave height was $159 \%$ of the design wave height (see Fig. 6). One Xbloc units was displaced in the final row of the slope (i.e. the row below the transition from slope to crest berm). Armour units at the transition to the crest berm were rocking in this conditions. The interlocking with units of the next lower row, the final row of the slope was therefore reduced.

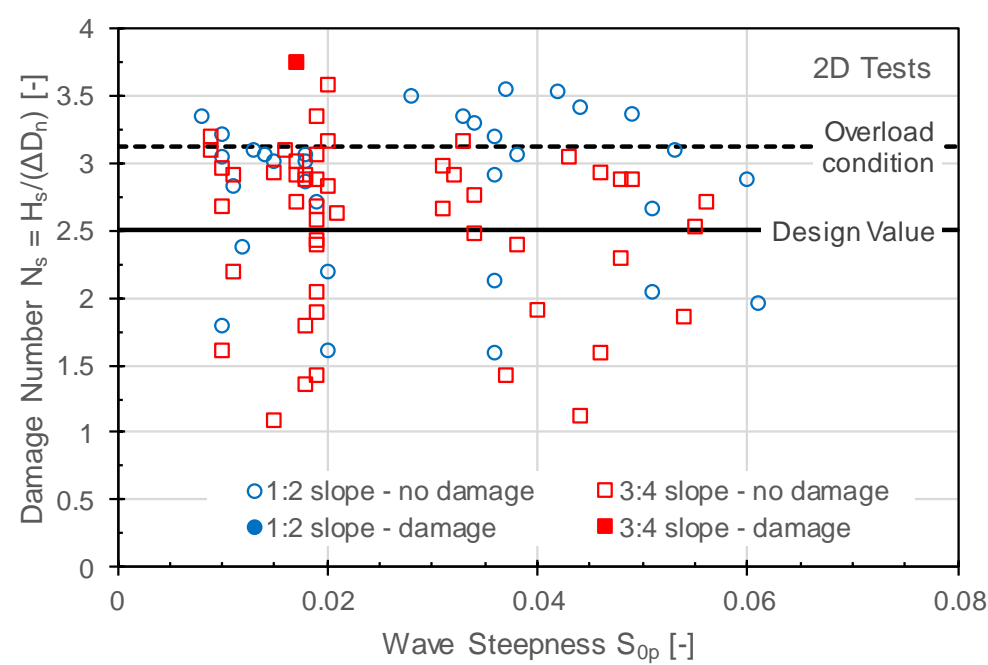

Figure 6: Stability number vs. wave steepness for $2 D$ tests with 1:2 and 3:4 breakwater slopes

\section{RESULTS FROM 3D STABILITY TESTS}

Two types of armour layer damage were considered in the 3D tests. The definition of displacement and settlement corresponds to the 2D tests. Rocking was not monitored in the 3D tests.

A geotechnical failure (slip failure) of the breakwater slope occurred in the tests section with XblocPlus armour. The incoming wave height, $\mathrm{H}_{\mathrm{s}}$ was $15.3 \mathrm{~cm}$ (ca. $160 \%$ of the design wave height), the wave period $\mathrm{T}_{\mathrm{p}}$ was $2.2 \mathrm{~s}$ (wave steepness $\mathrm{s}_{0, \mathrm{p}}$ was 0.02 ) and the wave direction was $30^{\circ}$. A major part of the breakwater slope failed; the slip circle ran most probably through the breakwater core. The deformation of the breakwater slope had already started in the preceding test (with 140\% conditions). The armour layer damage resulting from the slope failure is not considered as a stability limit of XblocPlus units. The tests was re-done after repair of the breakwater slope without armour layer damage (and is shown in Fig. 7 as "no damage").

No damage was observed in any of the 3D tests to the XblocPlus armour layer. Before the final test $\left(\mathrm{H}_{\mathrm{s}}=18.8 \mathrm{~cm}, \mathrm{~T}_{\mathrm{p}}=2.5 \mathrm{~s}, \mathrm{~s}_{0, \mathrm{p}}=0.02\right.$, wave angle $\left.0^{\circ}\right)$ with about $200 \%$ conditions an XblocPlus unit was removed near the waterline to investigate a possible damage progression. During the test one of the neighbouring units in the next higher armour unit row tilted sideward. No further damage was observed in this test.

\section{RESULTS FROM OVERTOPPING TESTS}

The EurOtop overtopping formula for rubble mounds predicts and non-dimensional overtopping rate that is primarily determined by freeboard, $R_{\mathrm{c}} / \mathrm{H}_{\mathrm{m} 0}$. Further to this reduction factors are applied for 
the effect of berm, shallow foreshore, slope roughness or oblique wave attack. The determination of roughness coefficients for the EurOtop formula is described by Pearson et al. (2005). Typical roughness coefficients are 1.0 for a plane impermeable slope, 0.40 for a rubble mound breakwater with rock armour and 0.44 with Xbloc armour.

Roughness is commonly described by the ratio of roughness element size and a length parameter that characterises the flow conditions. Constant roughness coefficients (i.e. roughness coefficients that are considered as a material property) as proposed by Pearson et al. (2005) and recommended by EurOtop (2018) are uncommon and would be meaningful only for a fixed ratio of armour size and hydraulic load (for example for near-design conditions). Roughness coefficients that were determined for near design conditions might not be applicable for significantly larger or smaller waves (Bakker et al., 2017).

Roughness coefficients were determined from overtopping tests with $60 \%$ to $100 \%$ of the design wave height. Tests with larger wave heights were not considered. From these tests a roughness coefficient, $\gamma$ of 0.45 was deduced. This coefficient is marginally larger than for other single layer interlocking armour units and comparable to single layer rock armour (EurOtop, 2018).

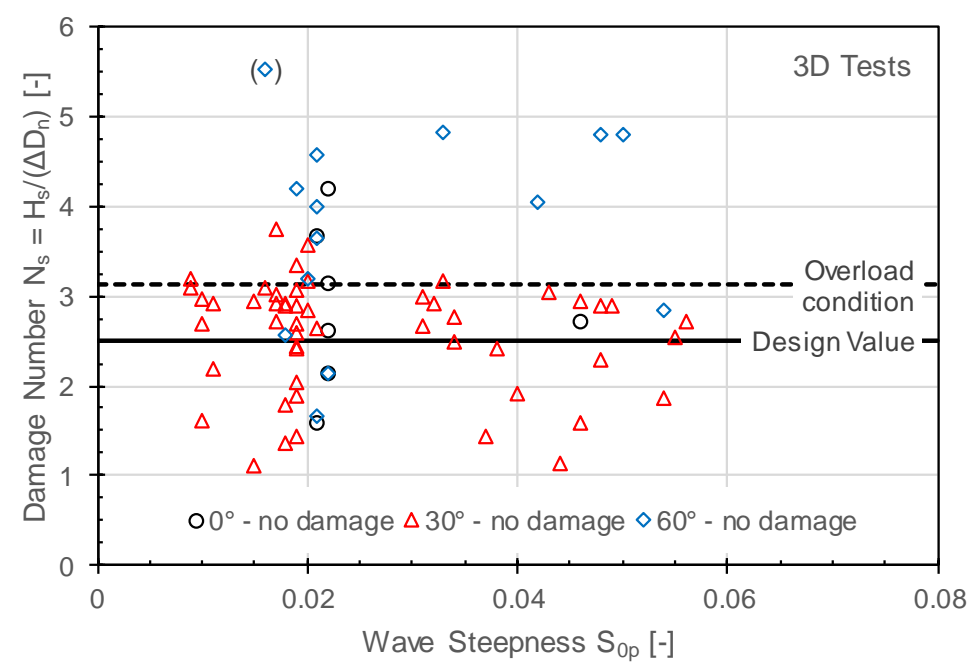

Figure 7: Stability number vs. wave steepness for $3 \mathrm{D}$ tests with wave direction $0^{\circ}, 30^{\circ}$ and $60^{\circ}$

\section{CONCLUSIONS}

The hydraulic stability of XblocPlus armoured slopes from the toe up to but not including the transition to the crest was tested in 2D and 3D hydraulic model tests. The model tests have demonstrated that the actual hydraulic stability exceeds the damage number, $\mathrm{N}_{\mathrm{s}}$ of 2.5 that is applied for design significantly. Even in overload conditions, i.e. in conditions with $20 \%$ or $25 \%$ exceedance of the design wave height virtually no damage can be expected. The model test results do not indicate any influence of wave steepness on XblocPlus stability. There is further no indication that XblocPlus stability would be adversely influenced by oblique waves. It appears that seabed slope in front of the breakwater has impact on the armour layer stability. The hydraulic stability in 2D tests with 1:30 seabed slope is probably less than in 3D tests with horizontal bed. This effect of seabed slope is in line with other types of interlocking armouring (Reedijk et al., 2010). The overtopping performance of XblocPlus armour units is not impaired by the regular placement pattern. The roughness coefficient of the EurOtop overtopping formula for rubble mound breakwaters that refers to the overtopping reduction due to roughness and permeability of the armour layer is similar as for other single layer interlocking armour units.

\section{ACKNOWLEDGEMENTS}

The invention of XblocPlus would have not been possible without the support by BAM Infra and by BAM Infraconsult. Their support for the armour unit development and for the operation of the hydraulic laboratory is acknowledged. Further to this the valuable input by Amber Vos, Maria Belen Rada Mora, Alba Jiménez Moreno, Danny Janssen and Ileen van den Berg who were testing and improving XblocPlus as part of their MSC theses is gratefully acknowledged. 


\section{REFERENCES}

Bakker, P., B. Reedijk, J. Manaois, M. van de Koppel, M. Muttray, Causes for increased wave overtopping on rubble mound breakwaters and revetments. ICE, Proc. Coasts, Marine Structures and Breakwaters 2017, Liverpool, UK (2017).

Berg, I. van den, Effect of irregularities in the under layer on the stability of XblocPlus concrete armour unit. MSc Thesis, Delft University of Technology, Delft, Netherlands (2018).

DMC, Guidelines for Xbloc concept design. Delta Marine Consultants, Gouda, The Netherlands, https://www.xbloc.com (2018).

EurOtop, Manual on wave overtopping of sea defences and related structures. $2^{\text {nd }}$ Edition, www.overtopping-manual.com (2018).

Jacobs, R., P. Bakker, I. Vos-Rovers, B. Reedijk, XblocPlus - Development of a regular placed interlocking armour unit. Poster, ASCE, $36^{\text {th }}$ International Conference on Coastal Engineering, Baltimore, Maryland (2018).

Janssen, D., Stability analysis of XblocPlus crest element. MSc Thesis, Delft University of Technology, Delft, Netherlands (2018).

Mansard, E.P.D., E.R. Funke, The measurement of incident and reflected spectra using a least squares method. ASCE, Proc. $15^{\text {th }}$ International Conference on Coastal Engineering, Sydney, Australian (1980).

Muttray, M., B. Reedijk, Design of concrete armour layers. Hansa, International Maritime Journal, Vol. 146, No. 6, pp. 111-118 (2009).

Muttray, M., J.S. Reedijk, I. Vos-Rovers, P. Bakker, Placement and structural strength of Xbloc and other single layer armour units. Proc. Coastlines, Structures and Breakwaters, ICE, pp. 556-567 (2005).

Pearson, Y., J.van der Meer, T. Bruce, L. Franco, Overtopping performance of different armour units for rubble mound breakwaters. International Coastal Symposium, Höfn, Iceland (2005).

Rada Mora, M.B., Hydraulic performance of XblocPlus armour unit. MSc Thesis, Delft University of Technology, Delft, Netherlands (2017).

Reedijk, B., M. Muttray, H. Bergmann, Risk Awareness - Key to a sustainable design approach for breakwater armouring. Proc. Coasts, Marine Structures and Breakwaters: Adapting to change, Vol. 1, pp. 96-107, (2010).

Vos, A. Exploration into the mechanisms that govern the stability of an XblocPlus armour unit. MSc Thesis, Delft University of Technology, Delft, Netherlands (2017). 